\title{
Uma conversa com o leitor: Entendendo as preferências do público a partir dos rastros de navegação na Fanpage do Jornal Correio Popular de Imperatriz (MA)
}

\author{
Marcelli Alves da Silva \\ Thaisa Cristina Bueno \\ Welbert de Sousa Queiroz \\ Universidade Federal do Maranhão - UFMA, Brasil
}

\section{CASE REPORT}

\begin{abstract}
Resumo
Objetivo: Este estudo se propõe a entender as predileções e comportamentos do leitor do jornal Correio Popular, de Imperatriz (MA), a partir da análise descritiva dos modos de navegação e interações ordenadas pelos internautas que integram os curtidores da fanpage do veículo no Facebook.

Método: A pesquisa está estruturada em três pilares metodológicos: estudo descritivo, categorização a partir de estudo qualitativo, e entrevista. $O$ estudo descritivo foi viabilizado por meio da análise dos dados do painel administrativo de acesso restrito aos administradores e gerenciadores da página, que foi liberado para essa pesquisa. O levantamento ocorreu entre os dias 12 de junho a 23 de junho de 2013. A etapa qualitativa prevê análise e categorização dos comentários inseridos na matéria mais comentada no período, a postagem somou 82 posts de leitores. Por último alguns dados são fruto de duas entrevistas, feitas com duas jornalistas que trabalham no jornal e monitoram a página.

Resultados: O resultado aponta algumas orientações para uso de fanpages para futuros jornais em formato semelhante. Conclusões: $O$ estudo possibilitou o entendimento de qual o papel das fanpages para os veículos, pelo menos em cidaes pequenas.
\end{abstract}

Palavras-chave

Comentários; Correio popular; Fanpage; Facebook; Internet.

A conversation with the reader: Understanding the preferences of the public from the navigation traces in the fanpage of the newspaper Correo Popular from Imperatriz (MA)

\begin{abstract}
Objective: This study proposes to understand the predilections and newspaper reader behaviors "Correio Popular', from Imperatriz (MA) starting at the descriptive analysis of the navigation means and interactions made by internet users who are part of the fanpage "likers" on Facebook.

Method: The research is structured in three methodological pillars: a descriptive study, categorization from qualitative study and interview. The descriptive study was made possible through the analysis of data from the administrative panel of restricted access to administrators and page managers, which was released for this research. The survey occurred between 12 June to 23 June 2013. The qualitative phase provides analysis and categorization of the comments inserted in the most talked about subject in the period,the post scored 82 posts from readers. Finally some data are the result of two interviews.

Results: Made with two journalists that work in the newspaper and monitor the page. The result shows some guidelines for use of fanpages for future newspapers in similar format.

Conclusions: The Study allowed the understanding of the function of fanpages for vehicles, at least in small cities.
\end{abstract}

Keywords

Correio Popular; Fanpage; Facebook Comments; Internet.

\section{Introdução}

As redes sociais na Internet trouxeram mudanças significativas no âmbito da comunicação. Isso não só na divulgação do conteúdo, mas também na forma de consumir essas informações. Em abril de 2015 o site Observatório da Imprensa divulgou um ranking produzido pela Agência Norte-Americana Quartz que destacava o primeiro lugar do Brasil como o país que mais consumia notícias por meio do Facebook. De acordo com esse 
levantamento, $67 \%$ dos brasileiros conectados na rede mundial de computadores usam a rede social para ter acesso às notícias. No âmbito nacional, outro levantamento, esse amplamente divulgado no site E-Dialogo Comunicação Digital, especializado em propagação de conteúdo e pesquisas voltadas para o ciberespaço, noticiou em 27 de fevereiro de 2013 as regiões que mais utilizam essa rede social no Brasil. A pesquisa constatou que os três maiores participantes são: o Distrito Federal, com 61,23\% da população com perfis na rede; seguida de São Paulo (50, 84\%) e do Rio de Janeiro (49, 96\%). No Maranhão, que de acordo com o IBGE (2010) é o Estado menos conectado do Brasil, cerca de 15\% (exatos 14,72\%) mantém um perfil no Facebook.

Embora o número seja pequeno se comparado com outros estados do Nordeste, como Alagoas, que é o 24ํㅜㄴ colocado, com 3.093.994 habitantes e 647.700 perfis; e o Piauí, 26ํㅡ colocado, com 3.096 .448 habitantes e 587.260 perfis, pode-se constatar que, caso a pesquisa tivesse levado em conta apenas o número de usuários, o Maranhão ficaria em $15^{\circ}$ lugar com 945.740 perfis, ou seja, uma posição mediana em relação aos demais Estados. Mais ou menos conectado às redes que seus vizinhos o fato é que, a exemplo do que acontece no restante do país, as empresas jornalísticas por aqui estão cada vez mais inseridas no Facebook.

Em Imperatriz, segunda cidade do Maranhão em numero de habitantes, os dois únicos periódicos impressos com tiragens maiores que 1.500 exemplares são os jornais O Progresso e o Jornal Correio Popular. Ambos possuem página na rede social Facebook e cada um deles conta com mais de 10.000 seguidores.

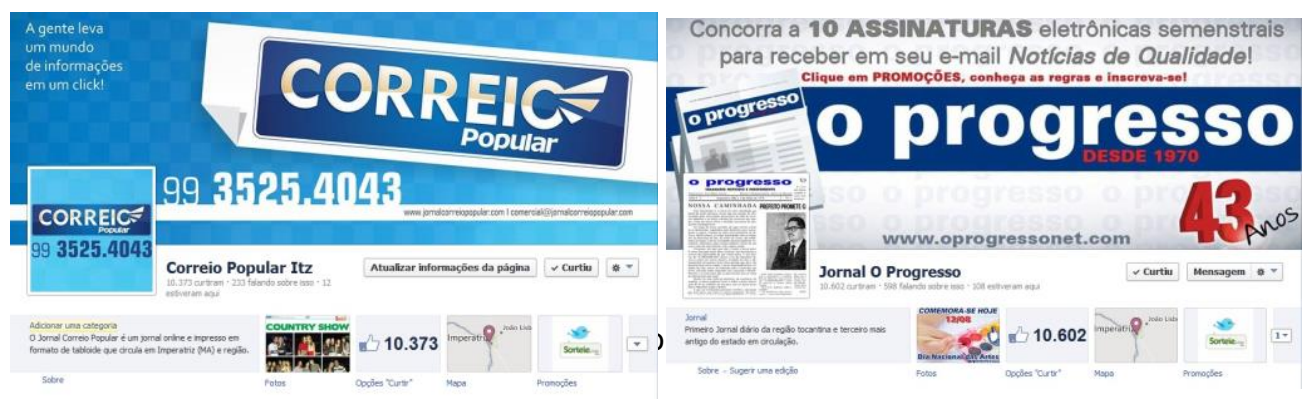

Figura 1 - Fanpages dos jornais de Imperatriz

Fonte: Correio Popular e O Progresso (2013).

E apesar de possuírem uma quantidade próxima de seguidores, o Correio Popular Itz foi escolhido como objeto desse estudo porque as interações na sua página são mais comuns. Enquanto cada postagem na página do jornal O Progresso contabiliza em torno de 1 a 5 comentários, na página Correio Popular Itz percebe-se uma quantidade bem maior, em média 15 comentários por postagem.

Diante do exposto, a proposta deste artigo é conhecer um pouco sobre o perfil desse internauta que segue e interage na página do jornal no Facebook para entender como acontece seu consumo na rede social, bem como descrever como o jornal faz uso da página para atrair os leitores. A pesquisa está estruturada em três pilares metodológicos: um estudo descritivo por meio da análise dos dados do painel administrativo de acesso restrito aos administradores e gerenciadores da página que foram liberadas para essa pesquisa. Foram estudados esse comportamento período de 12 de junho a 23 de junho de 2013; uma etapa qualitativa em que são analisadas as postagens da matéria mais comentada no período, a postagem que somou 82 posts de leitores. Nesse momento são categorizados esses comentários, afim de entender que tipo de interação é promovida ali; e por último alguns dados são fruto de duas entrevistas, feitas com duas jornalistas que trabalham no jornal e monitoram a página.

\section{Redes sociais e capital social}

Entende-se por rede social uma estrutura montada por pessoas ou organizações compostas por conexões e interações entre os "atores" por meio de valores, ideologias ou interesses em comum. As redes sociais se colocam no contexto de sociedade como uma forma de estrutura que, quando mediada por computador, ganha maior amplitude e flexibilidade, na medida em que podem atingir um número maior de participantes, mas também faculta serem desfeitas corriqueiramente. 


\begin{abstract}
Uma rede social é definida como um conjunto de dois elementos: atores (pessoas, instituições ou grupos; os nós da rede) e suas conexões (interações ou laços sociais) (Wasseman e Faut 1994; Degenne e Forse, 1999). Uma rede, assim, é uma metáfora para observar os padrões de conexão de um grupo social, a partir das conexões estabelecidas entre os diversos atores. A Abordagem de rede tem, assim, seu foco na estrutura social, onde não é possível isolar os atores sociais e nem suas conexões (RECUERO, 2009. p. 24).
\end{abstract}

Para Fontes (1999), as redes são pontes que ligam os "indivíduos" (pessoas, instituições ou grupos) e estruturam suas biografias em inserções sociais que garantem suas identidades. Castells (1999) destaca que para enxergar essa sociabilidade é necessário distinguir os laços sociais, categorizados por ele "laços fracos" e "laços fortes". A rede por si é especialmente adaptada para a geração de laços fracos múltiplos. Os primeiros têm utilidade quando se trata do fornecimento de informações, já que permite a relação com desconhecidos. As "comunidades virtuais", mesmo quando em formato de laços fracos, matem relevância social. Castells (1999) ressalva ainda que "não são irreais, funcionam em outro plano da realidade". No Facebook, particularmente em fanpages como as do jornal analisado aqui, os laços na maioria das vezes são fracos, porque em tese os atores integrantes daquele espaço compartilham o interesse pelo veículo, mas as aproximações terminam ali.

Se permitem a formação de rede social, é importante destacar que o Facebook, enquanto ferramenta de interação, nada mais é que um software social. Conforme Machado \& Tijiboy (2003) "são programas que funcionam como mediadores sociais e que favorecem a criação de redes de relacionamentos através de espaços onde o usuário pode juntar pessoas do seu círculo de relacionamentos". Os softwares ainda proporcionam a discussão de diversos temas, interação entre usuários, compartilhamento de interesses, entre outras potencialidades, construindo elos entre os atores por meio de conexões entre si ou entre o corporativo e o público.

Vale destacar que estes "canais sociais de comunicação", embora sejam necessários para o bom funcionamento de trocas informativas e de conversação, não devem ser confundidos como sendo uma "comunidade virtual" em si, pois no ramo das redes sociais, pelo menos no contexto do Facebook, surgem inseridos nestes softwares diversos softwares sociais que funcionam como um sistema orgânico que reúne as próprias "comunidades virtuais".

As empresas de comunicação entendem esse espaço de mediação como um ambiente de interesse não apenas informacional, mas como ambiente de interesse econômico, de marketing e de comunicação quando despertam para o potencial de relacionamentos que ela permite, sem contar a complexidade de suas funções.

\title{
30 Correio Popular no Facebook
}

O jornal Correio Popular, na versão impressa, está presente em Imperatriz desde março de 2011 e possui uma tiragem diária aproximada entre 1.500 a 2.500 exemplares distribuídos pela cidade. Apesar desse veículo de comunicação já possuir um perfil no Facebook desde 2011, só em 25 de fevereiro de 2013 fez sua migração de perfil para uma FanPage, assumindo uma postura mais profissional na rede. No período dessa pesquisa, a página deste veículo podia ser encontrada no Facebook com o nome de Correio Popular Itz.

Correio Popular entrou no ciberespaço tanto para o site no endereço http://www.jornalcorreiopopular.com quanto para sua FanPage no Facebook pelo link https://www.facebook.com/CorreioPopular embora o foco principal dessa ação estivesse relacionada mais à divulgação do produto tradicional, impresso, no ciberespaço que à necessidade de explorar as potencialidades da ferramenta e criar conteúdo próprio. Tanto é assim que o jornal não chegou a organizar uma equipe para produzir conteúdo para a web, replicando no site e rede social o material já divulgado na página de papel.

Os jornais impressos "Correio Popular" e "O Progresso" possuem um site cada um, com a versão online dos periódicos que são atualizados diariamente, sempre reproduzindo as notícias publicadas na versão impressa. Os dois têm perfil no Facebook que são utilizados diariamente para divulgar a publicação do jornal do dia (DUTRA, 2013. p.45).

No período desse estudo, o jornal atuava em quatro frentes: uma impressa (jornal) e outras três por intermédio da internet: site, FanPage no Facebook e um perfil na rede social Twitter. 


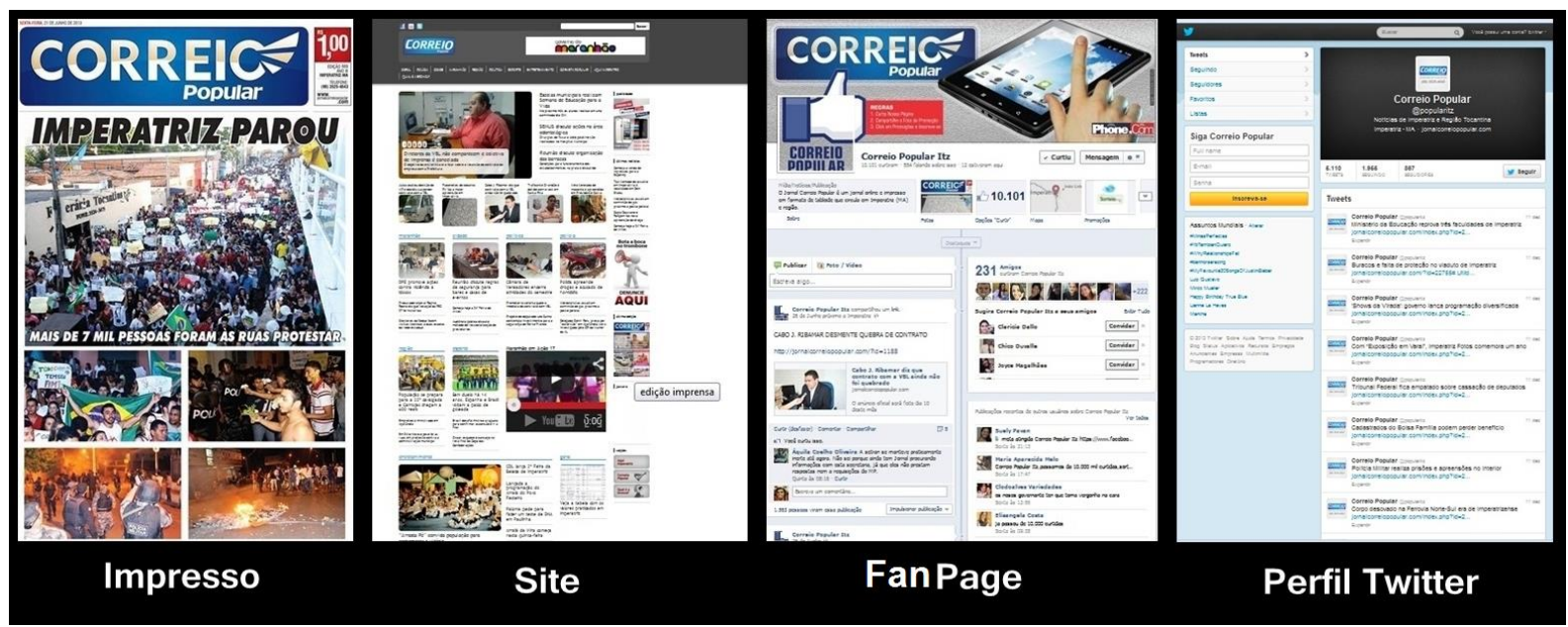

Figura 2 - Páginas do Correio Popular em diferentes plataformas

Fonte: Os autores (2013) - adaptado.

Para esse estudo, os pesquisadores conseguiram licença para analisar por uma semana o painel administrativo de acesso restrito aos administradores e gerenciadores da página. Neste painel é possível observar e gerenciar as publicações do veículo de comunicação, conhecer o percurso de leitura e comportamento do leitor. A página ainda possibilita a geração de gráficos e estatísticas para que os administradores possam elaborar estratégias referentes ao seus objetivos com relação a essa mídia digital.

Aparentemente simples, essa ferramenta "esconde" várias possibilidades e funcionalidades para a divulgação de conteúdo e geração de feedback - por interatividade - nesse universo que se demonstra cada vez mais relevante em relação aos meios tradicionais.

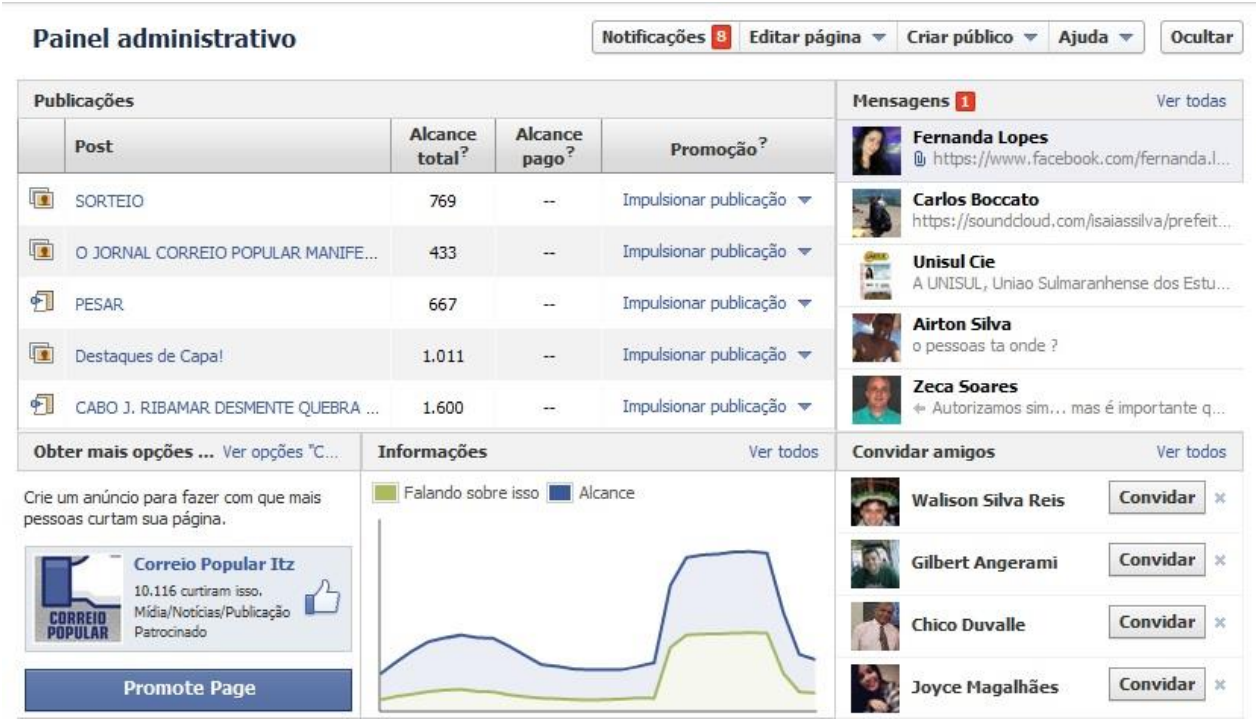

Figura 3 - Painel administrativo do jornal Correio Popular Fonte: Facebook, Correio Popular (2013).

A motivação para a escolha deste período é que entre estas datas houve um aumento significativo em relação ao alcance das publicações, que vinham se mantendo em uma constância, havendo também um súbito aumento que se manteve por um período e, em seguida, retroagiu para a frequência casual da página. 
Observou-se que a média de alcance da página é em torno de 10.000 pessoas. No dia 12/06, o alcance era de 9.178 (início da análise) e, no dia 23/06, de 11.124 (final da análise). No gráfico que segue, as bolas roxas apresentam o número de publicações, a linha verde apresenta o número de pessoas que criaram histórias a partir das publicações e a linha azul apresenta o número de pessoas que visualizaram a página no período de uma semana.

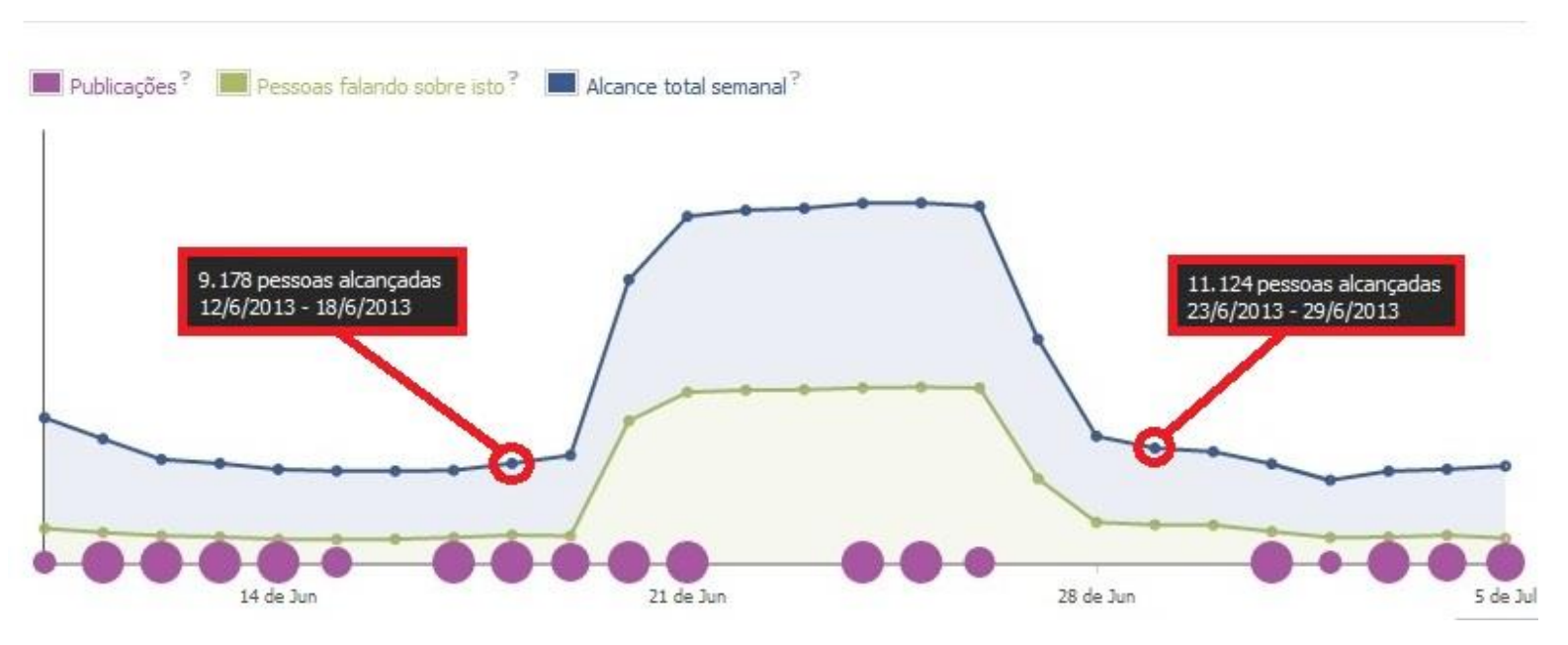

Figura 4 - Alcance inicial e final do período de análise da FanPage Fonte: Facebook, Correio Popular (2013).

Os pontos de picos de alcance da página contabilizavam em torno de 50.000 pessoas alcançadas com a postagem. Em termos comparativos, esse número corresponde a $1 / 5$ da população imperatrizense, considerando que a cidade possui 250 mil habitantes, segundo o senso de 2010 do IBGE. No dia 20/06, dia escolhido para a análise dos comentários dos leitores na postagem mais comentada, a página teve um alcance total semanal de 50.682 pessoas.

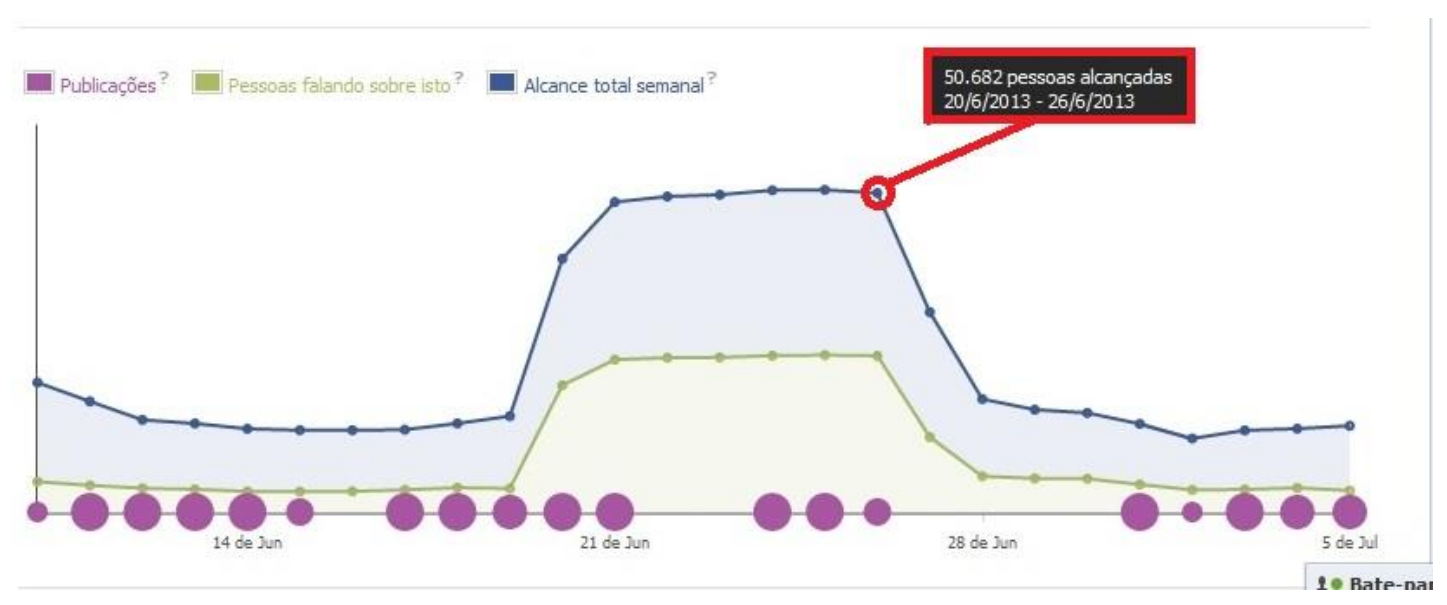

Figura 5 - Número de pessoas alcançadas no dia 20 de junho

Fonte: Facebook, Correio Popular (2013).

Considerando o alcance de todos os dias analisados, a FanPage obteve o número total de alcance semanal de 409.907 mil pessoas. Esses números representam, claro, a soma das visualizações diárias, o que não exclui a possibilidade de um mesmo usuário ter visualizando postagens diferentes em dias diferentes. Outro fator interessante que o gráfico mostra é que não há uma relação direta entre o número de publicações e o número de alcance. Ao que parece, o alcance se dá não pelo quantitativo, mas pela simples qualidade e relevância ao que se é postado. 
O perfil dos curtidores e comentadores também foi possível de constatar no levantamento do período. Do que se pode observar, as porcentagens entre pessoas do sexo masculino e feminino são bastante equilibradas. Com variação em torno de $4 \%$, as mulheres estão à frente dos homens em número e em todas as faixas etárias. A maioria dos curtidores estão na faixa etária entre 18 e 34 anos, contabilizando perto de $40 \%$ do total de quem participa da FanPage do Correio Popular Itz. A localização das interações ratifica a tendência regional do veíulo. Neste período, tem-se como um dos fatores analisados a localização das pessoas que interagem nesta página: países, cidades e idiomas. 9.857 destes usuários são brasileiros, em sua maioria de Imperatriz (MA), com 7.183 usuários que definem seu idioma como português brasileiro, contando com 9.754 personagens.

\section{Conhecendo o Correio Popular ITZ}

No período analisado foi possível perceber, por exemplo, que o leitor não costuma comentar matérias que são na verdade um link para postagem do site. O estudo descritivo notou que os comentários dos leitores concentravam-se em matérias com texto produzido para a rede social, mesmo que fosse um resumo e apontasse para o link da matéria completa, e que tivesse fotos. Ou seja, o simples compartilhamento do link da matéria não atraia os leitores, mostrando que a internauta lia mais os textos com uma abertura inédita produzida especificamente para o dispositivo.

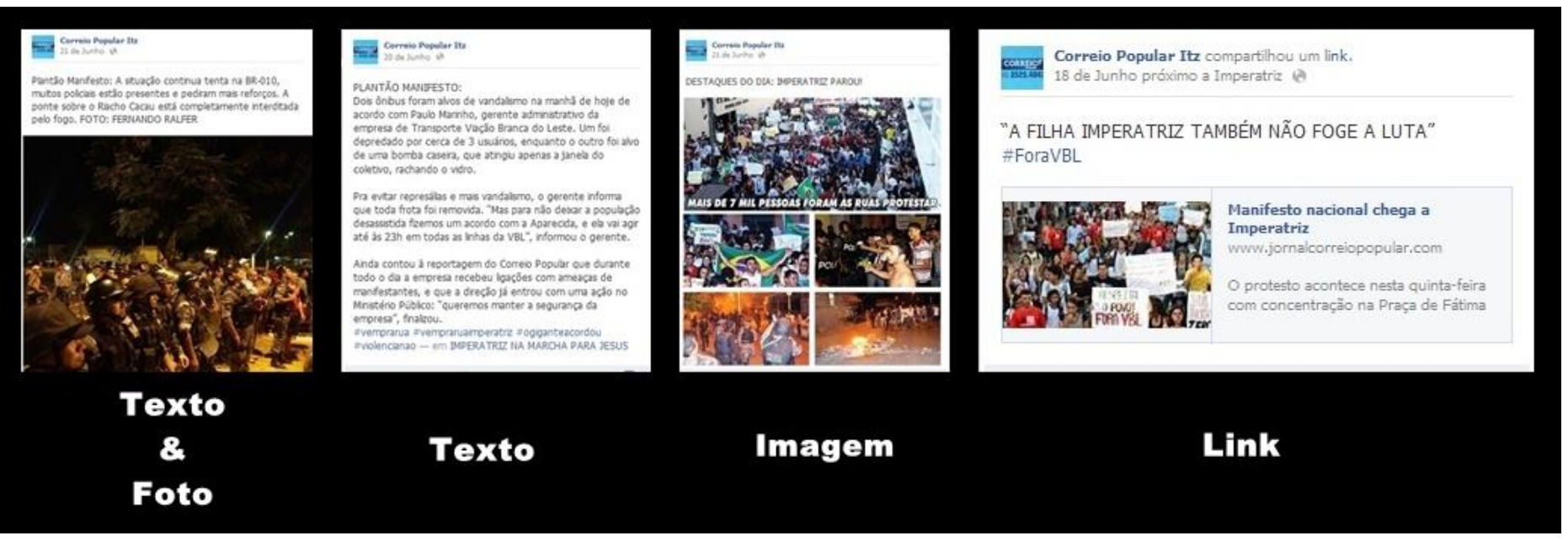

Figura 6 - Tipos de postagens na FanPage

Fonte: Facebook, Correio Popular (2013).

Inclusive, quando a Fan Page do Correio Popular Itz publica textos exclusivos (uma raridade na rotina do veículo) são os que mais contabilizam comentários. Enquanto um compartilhamento de link não chega a 5 curtidas, um texto adequado ao meio chega a pelo menos 25 curtidas e ultrapassa facilmente a marca de 15 comentários.

Outro ponto observado e que contribui para o entendimento dos sentidos que a plataforma agrega ao jornal diz respeito ao total de "visualizações da guia". Esse recurso expõe a quantidade de vezes em que cada uma das guias da página foi vista em suas segmentações dentro da plataforma. A imagem também mostra as "referências externas", que são as quantidades de vezes que a página foi aberta a partir de uma URL ${ }^{1}$ que não faz parte do Facebook neste período.

\footnotetext{
${ }^{1}$ Um URL (de Uniform Resource Locator), em português Localizador-Padrão de Recursos, é o endereço de um recurso (um arquivo, uma impressora e etc.), disponível em uma rede; seja a Internet, ou uma rede corporativa, uma intranet. Uma URL tem a seguinte estrutura: protocolo://máquina/caminho/recurso <Wiki>
} 


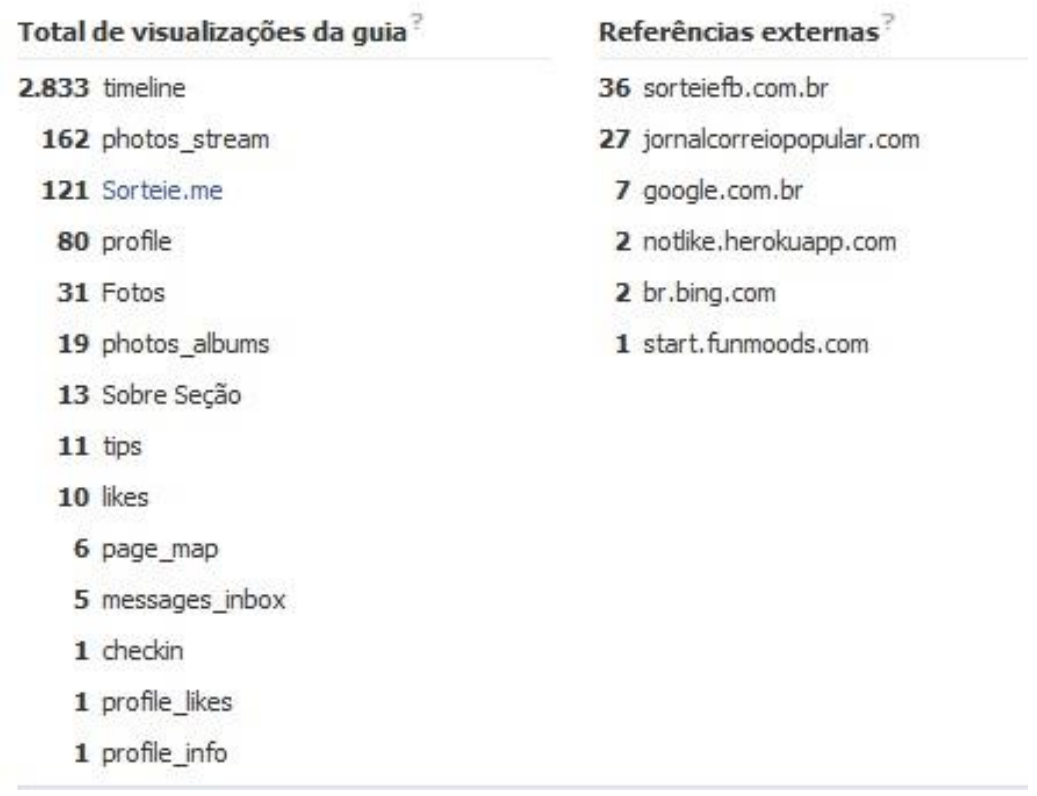

Figura 7 - Total de visualizações da guia e Referências externas

Fonte: Facebook, Correio Popular (2013).

Vê-se claramente que depois da Timeline, que é a página de abertura da página, fotografias e promoções são dos espaços com mais visualização e nos quais o leitor fica por mais tempo.

No gráfico a seguir, cada ponto representa um apanhado do alcance das publicações separadas por categorias; "Sistemático", é o número de pessoas que visualizaram no Feed de Notícias, em "novidades" ou na página; "Pago", que são os anúncios ou histórias patrocinadas com um 'link' que redirecionavam para a página e "Viral", que é número de pessoas que viram essa história publicada por meio dos amigos. Essas histórias incluem as opções "Curtir", "Publicação", "Comentários" ou "Compartilhamentos" das publicações na página, além de outras ações relacionadas à página publicadas por amigos.

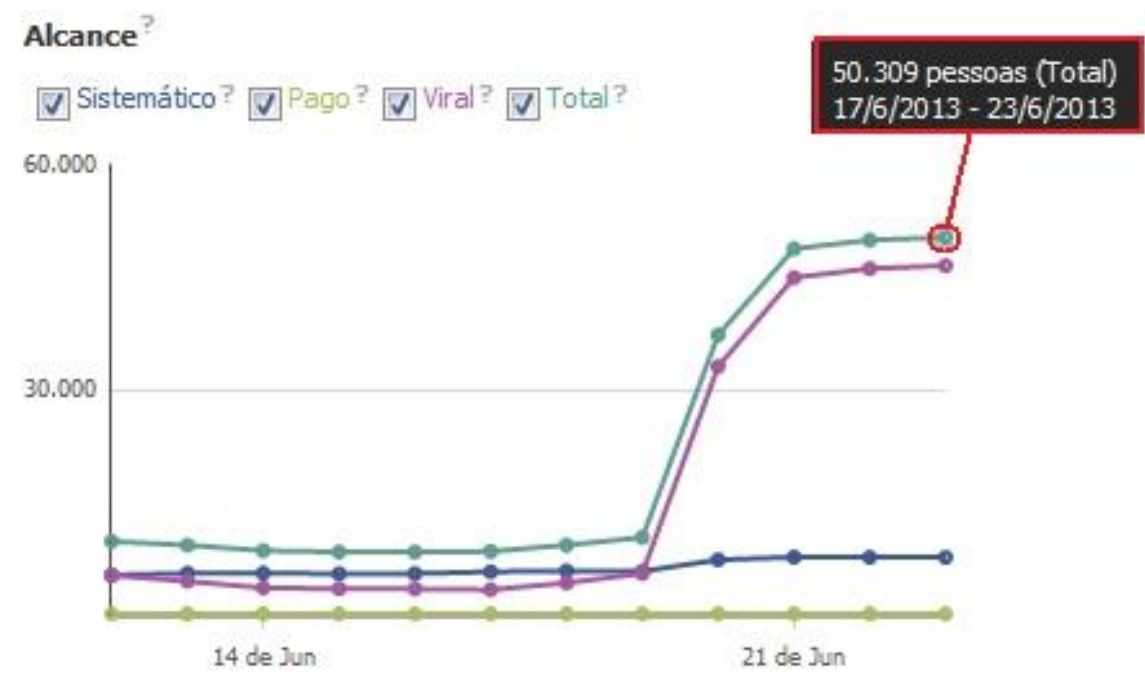

Figura 8 - Caminhos utilizados pela FanPage para alcançar os números de visualizações 


\section{Fonte: Facebook, Correio Popular (2013).}

Este gráfico mostra o alcance em visualizações da página neste período. Essas pessoas foram alcançadas por meio do "canal orgânico", "pago" ou "viral'. Como esses usuários podem visualizar através de mais de um desses canais, o número total pode aparecer ainda mais alto que o alcance viral, pois o total abarca todos os dados em uma única estatística.

Assim, os efeitos foram de: "Sistemático", com 7.546 visualizações; "Pago", com 0 visualizações; "Viral”, detendo 46.551 das visualizações e "Total", com 50.309. O apontamento do gráfico deixa claro que a FanPage do jornal faz uso da divulgação de forma gratuita, focalizando apenas na divulgação disponível pela ferramenta, sem custos e por meio da divulgação dos leitores.

\section{Conversação no Correio Popular Itz}

A partir daqui, depois da descrição da página e do entendimento inicial do comportamento do usuário e também do veículo nesse espaço, a pesquisa dedica-se a analisar os comentários dos leitores na postagem mais comentada do período. Uma matéria sobre as manifestações de junho de 2013 no Brasil, publicada como 'Plantão manifesto. Milhares de pessoas lotam a Luis Domingues". Na análise dos 82 comentários encontramos algumas imanências.

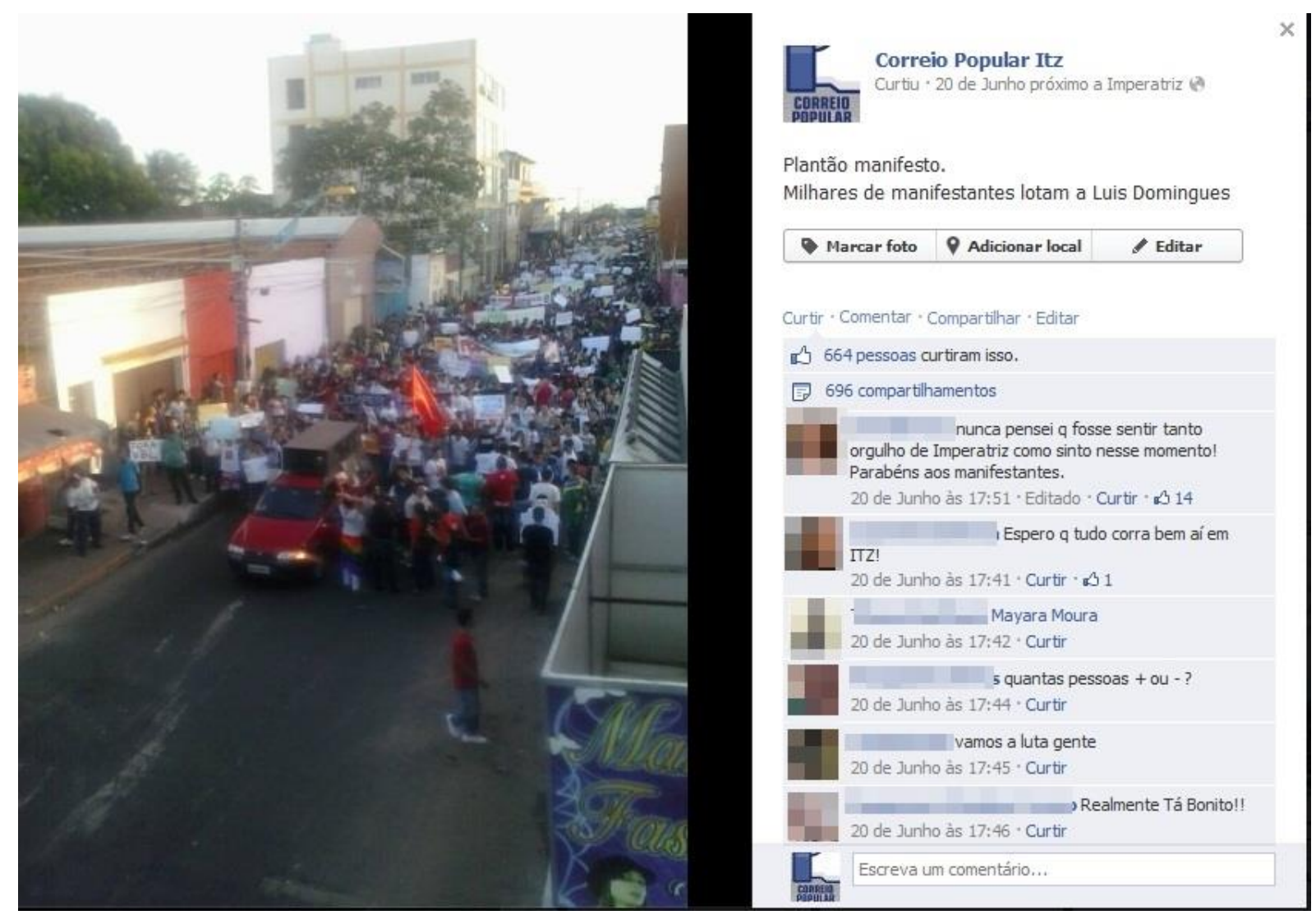

Figura 9 - Postagem da página utilizada para a análise

Fonte: Facebook, Correio Popular (2013).

Em sua maioria, os usuários se expressam e emitem opiniões a respeito da postagem, como é o caso de:

- Marinho: Vamos lá, IMPERATRIZ, lutar pelos nossos direitos... 
Neste fragmento, percebe-se que o comentário do curtidor da página expressa sua opinião com relação ao fato ocorrido. Esta conversação faz menção tanto à postagem quanto a todos os demais atores que participam da conversação.

Outro ponto a ser observado é a conversação que ocorre entre os leitores dentro da postagem. Alguns usuários aproveitam a conversação para complementarem a notícia divulgada e se informarem em um aspecto colaborativo de interação. É o que acontece entre os leitores Costta e Araújo:

\section{- Costta: Que rua é esta?}

- Babu: (...)

- Pinheiro: (...)

- Araújo: Luís Domingues

Além desses exemplos o estudo buscou, na análise dos 82 comentários da material selecionada, criar uma categorização dos tipos de postagens mais comuns. Sendo que a postagem em si alcançou 664 curtidas e 696 compartilhamentos. Decidiu-se a partir da leitura dos comentários desta amostra categorizá-los em:

a) Contextualizados: Comentários que estejam diretamente ligados ao assunto publicado. Ex:

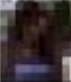

Alves $\mathrm{E}$ isso ai, meu povo! Agora vai!

20 de Junho às $18: 29 \cdot$ Curtir

b) Menções: Comentários em que o leitor faz uma marcação de outro leitor para que a postagem seja mencionada (direcionada) a este leitor por meio de marcação (ferramenta disponível no Facebook que possibilita a marcação de um leitor para que este visualize a postagem). Ex:

FT In - Sandna Olha ai Camylla Laryssa Yarah Souza Nittch tamo perdendo

20 de Junho às $18: 21$ via celular · Curtir

c) Opinativos: Comentário opinativo que perpasse a questão de estar atrelado ao texto ou simplesmente ligado ao assunto. Estes são comentários com criticidade ou protesto à postagem apresentada pela FanPage. Ex:

\section{Veloso PElo AMor de Deus alguém arranca} essas bandeira de merda de partido.. Isso é um movimento Apartidário não aceitem isso.. Políticos sujos e aproveitadores de uma boa causa... Amém.

20 de Junho às $18: 23 \cdot$ Curtir - 37

d) Colaborativos: Comentários entre os leitores que discutam alguns assuntos ou que complementem a postagem a partir de seus comentários. Ex:

Alves quantas pessoas + ou - ?

20 de Junho às $17: 44$. Curtir 
e) Simbólicos: Demais comentários como as HashTags (\#), interjeições ou marcas de expressão, como risos (kkkkkkkk, rsrsrsrsr, uhauhahaahu). Apropriações criadas pelos próprios usuários em rede. Ex:

Samya
KKKKKKKKKKKKKKKKKKKKKKKKKKKKKKKKKKKKKKKKKKKKKKKKKKKKKKKKKK
21 de Junho às $10: 05 \cdot$ Curtir

21 de Junho às $10: 05 \cdot$ Curtir

Com isso, chega-se ao gráfico a seguir:

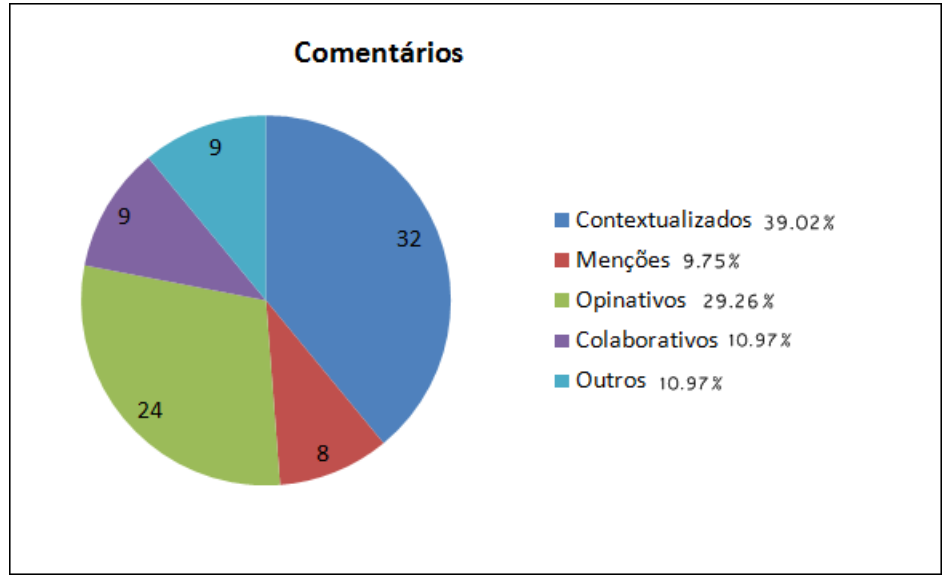

Gráfico 1 - Gráfico sobre os tipos de comentários do Plantão Manifesto: postagem com 82 comentários

Fonte: Os autores (2013)

Constata-se com essa amostra de comentários que a maiorias destes estão relacionados ao conteúdo postado. Os leitores comentam, em sua maioria, emitindo opiniões e contextualizando o assunto publicado, somando um percentual de quase $69 \%$. Além de divulgarem os conteúdos por meio de menções e colaborações, levam essas conexões até mesmo para apropriações de linguagem características da rede.

\section{FanPage Correio Popular Itz aos olhos dos profissionais}

A última etapa do estudo buscou entender o uso e o papel da FanPage do Correio Popular a partir do olhar dos seus profissionais. Assim foram entrevistadas duas jornalistas (uma editora e outra repórter do veículo) que atuavam também na atualização da página da mídia na rede social: a editora Karolina Damião e a repórter Hyana Reis. As entrevistas aconteceram em abril de 2013. Na época o jornal mantinha 10 funcionários entre jornalistas, recepcionista, designers e operador de máquina gráfica. As ponderações mais significativas foram organizadas em uma tabela que segue:

Tabela 1: Opinião das jornalistas do Correio Popular sobre a FanPage do jornal

\begin{tabular}{|l|l|l|l|}
\hline \multicolumn{1}{|c|}{ Profissional } & \multicolumn{1}{|c|}{ Relevância dos comentários } & \multicolumn{1}{c|}{ Contribuição } & \multicolumn{1}{c|}{ Particularidadde } \\
\hline Editora & $\begin{array}{l}\text { Mediante essa avaliação } \\
\text { conseguimos determinar o que } \\
\text { agrada ou desagrada nosso público. }\end{array}$ & $\begin{array}{l}\text { Para sugestão de } \\
\text { pauta }\end{array}$ & $\begin{array}{l}\text { Leitores comentam mais } \\
\text { temas polêmicos }\end{array}$ \\
\hline Repórter & É o retorno que o leitor dá ao jornal & $\begin{array}{l}\text { Permitem pensar } \\
\text { outros ponto de vistas } \\
\text { sobre a cobertura }\end{array}$ & $\begin{array}{l}\text { Os comentários são mais de } \\
\text { opinião sobre o tema e } \\
\text { menos de colaboração. }\end{array}$ \\
\hline
\end{tabular}

Fonte: Os autores (2013). 


\section{Considerações finais}

A partir do que foi analisado alguns pontos parecem ajudar a entender o papel das Fanpages para os veículos, pelo menos nas realidades de cidades pequenas e médias, onde boa parte dos veículos tem uma estrutura pequena, quando não precária, como é o caso do veículo analisado nesse estudo.

Um ponto que chamou bastante atenção é que sim, o monitoramento dos dados, por meio das estatísticas, é uma resposta material que permite o veículo conhecer de perto o perfil do seu leitor e suas predileções. Isso se mostra um recurso muito rico para que o jornal potencialize esse diálogo. Inclusive, um ponto a ser debatido é que esse monitoramento deveria ser repassado aos jornalistas, já que são eles que lidam diretamente com a notícia, as sugestões de pauta e manutenção da página. Nesse sentido o estudo mostra que esses dados não deveriam ficar restritos às equipes técnicas, já que seu conteúdo dialoga diretamente com a redação.

Outro ponto importante que o estudo mostrou é que cada suporte tem suas peculiaridades e estas não deveriam ser ignoradas pelas equipes de Jornalismo. Isso significa dizer, entre outras coisas, que cada plataforma vai requerer um conteúdo novo, pensado para ela. Na pesquisa mostrou-se que o leitor interage mais em postagens exclusivas, ou seja, quem vai à página da rede social do veículo não está interessado no conteúdo impresso, mas numa complementação dele ou mesmo uma novidade.

Os tipos de comentários também dão uma noção sobre a interação que o internauta está interessado. Na maioria das vezes está interagindo entre si, inclusive contribuindo com informações. Isso é um resultado bastante positivo, já que em geral tem-se criticado muito o conteúdo dos comentários por conta das rivalidades e discursos pouco educados. Nesse estudo vimos que é possível usar a plataforma para outros modelos de conversação.

O levantamento destaca, ainda, que a equipe de redação, mesmo não tendo estrutura muitas vezes para acompanhar e interagir como seu leitor, entende a plataforma como um resultado real de entender suas predileções e até repensar seus enfoques. Ou seja, é uma maneira possível de se aproximar do consumidor do conteúdo.

\section{Referências}

CASTELLS, Manuel. A Sociedade em rede. Manuel Castells; tradução Roneide Venancio Majer; atualização para 6a edição: Jussara Simões. (a era da informação: economia, sociedade e cultura. São Paulo. Paz e terra, 1999. Impresso no Brasil, 2009.

DUTRA, Carla Rejane Elias. O papel das redes sociais na rotina produtiva das empresas jornalísticas de Imperatriz. Monografia (Graduação em Comunicação Social) - Curso de Comunicação Social Habilitação Jornalismo, Centro de Ciências Sociais, Saúde e Tecnologia (CCSST), Universidade Federal do Maranhão, Imperatriz, 2013.

FONTES, B. A. S. Maior. Capital Social e Terceiro Setor: sobre a estruturação das redes sociais e associações voluntárias. CADERNO CRH, Salvador, n. 30/31, p. 239-264, jan./dez. 1999.

IBGE. Instituto Brasileiro de Geografia e Estatística. Mapa da Inclusão Digital. Maio de 2012.

MACHADO, Joicemegue Ribeiro. TIJIBOY, Ana Vilma. Redes Sociais Virtuais: um espaço para Efetivação da aprendizagem cooperativa. CINTED-UFRGS, v.3 N 1, maio, 2005.

RECUERO, Raquel. A conversação em rede: comunicação mediada pelo computador e redes sociais na Internet. Porto Alegre. Sulina, 2012

. Redes Sociais na internet. Porto Alegre, Sulina, 2009.

. Redes Sociais na Internet, Difusão de Informação e Jornalismo: Elementos para discussão. In SOSTER, Demétrio de Azeredo; FIRMINO, Fernando. (Org.). Metamorfoses jornalísticas 2: a reconfiguração da forma. Santa Cruz do Sul: UNISC, 2009. 


\section{Datos de los autores}

Marcelli Alves da Silva

Doutoranda em Comunicação (Jornalismo e Sociedade) na Universidade de Brasília, UnB. É professora assistente da Universidade Federal do Maranhão (UFMA). Possui graduação em Comunicação Social com ênfase em Jornalismo pela Universidade Federal de Mato Grosso do Sul (1999), especialização em Imagem e Som (2002 UFMS), Mestrado em Produção e Gestão Agroindustrial (2005 Uniderp) e Especialização em Gestão de Negócios de IES (Universidade Estácio de Sá do Rio de Janeiro.

alves.marcelli@yahoo.com.br

\section{Thaisa Cristina Bueno}

Jornalista formada pela UFMS, possui doutorado em Comunicação Social pela Pontifícia Universidade Católica do Rio Grande do Sul (2015) e Mestrado em Letras pela Universidade Federal de Mato Grosso do Sul (2007). Integra do grupo de pesquisa em Ciberjornalismo, numa parceria entre UFMS e UFMA, desde 2009, e coordena no Maranhão o Grupo de Pesquisa em Comunicação e Cibercultura.

thaisabu@gmail.com

\section{Welbert de Sousa Queiroz}

Jornalista, formado pela Universidade Federal do Maranhão (UFMA), e pós-graduado em Docência do Ensino Superior pelo Instituto de Ensino Superior Franciscano (IESF), em Imperatriz. Participou do grupo de Pesquisa em Novas Tecnologias e Mídias Sociais (G-Mídia), contribuindo como pesquisador em análise de conteúdos publicados em redes sociais. Experiência como assessor de comunicação na UFMA e também como repórter pelo Jornal Correio Popular, onde escreveu ainda uma coluna sobre educação (Coluna \#Intervalo). welbert.queiroz@hotmail.com

Recebido - Received: 2016-04-15

Aceitado - Accepted: 2017-03-22

\section{(cc) EY}

This work is licensed under a Creative Commons Attribution 4.0

United States License.

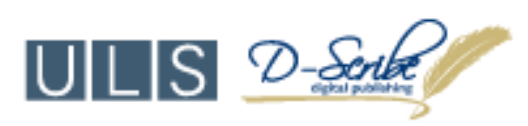

This journal is published by the University Library System of the University of Pittsburgh as part of its D-Scribe Digital Publishing Program and is cosponsored by the University of Pittsburgh Press. 